\title{
Preferential accumulation of sex and Bs chromosomes in biarmed karyotypes by meiotic drive and rates of chromosomal changes in fishes
}

\author{
WAGNER F. MOLINA ${ }^{1}$, PABLO A. MARTINEZ ${ }^{1}$, LUIZ A.C. BERTOLLO ${ }^{2}$ and CLAUDIO J. BIDAU ${ }^{3}$ \\ ${ }^{1}$ Departamento de Biologia Celular e Genética, Centro de Biociências, Universidade Federal \\ do Rio Grande do Norte, Av. Salgado Filho, 3000, Lagoa Nova, 59078-970 Natal, RN, Brasil \\ ${ }^{2}$ Departamento de Genética e Evolução, Universidade Federal de São Carlos, \\ Rodovia Washington Luís, Km 235, 13565-905 São Carlos, SP, Brasil \\ ${ }^{3}$ Departamento de Ingeniería en Biotecnología, Universidad Nacional de Río Negro, \\ Sede Alto Valle, Subsede Villa Regina, Tacuarí, 669, 8336, Villa Regina, Argentina \\ Manuscript received on November 28, 2013; accepted for publication on May 13, 2014
}

\begin{abstract}
Mechanisms of accumulation based on typical centromeric drive or of chromosomes carrying pericentric inversions are adjusted to the general karyotype differentiation in the principal Actinopterygii orders. Here, we show that meiotic drive in fish is also supported by preferential establishment of sex chromosome systems and B chromosomes in orders with predominantly bi-brachial chromosomes. The mosaic of trends acting at an infra-familiar level in fish could be explained as the interaction of the directional process of meiotic drive as background, modulated on a smaller scale by adaptive factors or specific karyotypic properties of each group, as proposed for the orthoselection model.
\end{abstract}

Key words: Actinopterygii, B chromosomes, centromeric drive, chromosome evolution, sex chromosomes.

\section{INTRODUCTION}

Most cytogenetic analyses within single families, especially in Neotropical species, suggest that karyotypic diversification occurred by the accumulation of population changes, either as a consequence of vicariant events involving large basins or geographic areas or by the fixation of chromosomal rearrangements in small isolated populations (Bertollo et al. 2000, Vicari et al. 2006, Molina et al. 2012).

Allopatric isolation seems to act in accordance with the peculiar biological patterns of distinct fish groups in the fixation of chromosomal rearrangements

Correspondence to: Wagner Franco Molina

E-mails: molinawf@yahoo.com.br / molinawf@pq.cnpq.br
(Molina and Galetti 2004). About 43\% (11,952) of fish species exclusively inhabit freshwater rivers and lakes, which cover only $1 \%$ of the Earth's surface. The remaining fish species $(15,800)$ live in the oceans, which encompass $70 \%$ of the Earth's surface and represent $97 \%$ of all existing water (Berra 2001). This distribution pattern coincides with the higher karyotype diversification found in continental species compared to marine species (Brum 1995), highlighting the potential of biogeographic barriers, which are more evident in continental areas.

Because of the large size of the group and its geographic distribution, fish have developed multiple adaptive strategies and biological patterns. They can form populations of tens to thousands of 
individuals, can be migratory or have restricted mobility, inhabit marine, freshwater, or estuarine habitats, and can survive in lothic or lentic ecosystems from a few to thousands of meters deep (Helfman et al. 2009). Fertilization can be internal or external; they may or may not take care of offspring; may be gonochorists or hermaphrodites (synchronous or asynchronous), and may exhibit multiple kinds of sex determination, such as polygenic, environmental, social, or chromosomal (Devlin and Nagahama 2002, Bone and Moore 2008). These biological conditions, individually or jointly, may also contribute to higher or lower karyotypic diversification between groups.

Several hypotheses have been considered with respect to karyotypic evolutionary trends in vertebrates. Some models have been more frequently applied to particular fish groups, e.g., the canalization model (Bickham and Baker 1979), karyotypic orthoselection and stasipatric speciation (White 1978), but many other alternatives have been proposed, although there is scant evidence for generalization (King 1981, 1993).

Unlike other vertebrates, fish chromosome diversification models are generally absent, with few exceptions. Molina (2007) found evidence of karyotypic orthoselection (sensu White 1973) in Perciformes and Tetraodontiformes, where some clades clearly exhibit a propensity for the fixation of certain kinds of chromosomal rearrangements at the expense of others.

Partial analysis of cytogenetic data for some orders has revealed diversified karyotypic trends within some clades showing marked conservatism (Motta-Neto etal.2011a, b, 2012), as well as extensive chromosomal changes in other clades where the occurrence of B chromosomes, differentiated sex chromosomes, structural polymorphisms, and/or spontaneous or fixed polyploidy have been reported (Galetti et al. 2000, Comber and Smith 2004, Almeida-Toledo et al. 2007, Molina et al. 2007, Oliveira et al. 2007).
Meiotic drive (MD) is the process by which one member of a pair of homologous chromosomes is preferentially recovered in the progeny of a heterozygous individual, independent of fitness. Although it can occur during male meiosis (Wyttenbach et al. 1998), the vast majority of cases have been described in female meiosis, which is almost universally asymmetric (Talbert et al. 2009). MD has been studied in a wide range of organisms such as plants, animals and fungi (Zimmering et al. 1970, Lyttle 1993, LeMarie-Adkins and Hunt 2000, Yoshida and Kitano 2012). B chromosomes and sex chromosomes frequently undergo MD (Camacho et al. 2000, Hoekstra and Hoekstra 2001, Bidau and Martí 2004, Palestis et al. 2004a, b, Rutkowska and Badyaev 2008, Ross et al. 2009, Uller and Badyaev 2009) as do autosomes.

Associations between MD and sex chromosomes and Bs chromosomes have yet to be described in fish. The precise recognition of the forces promoting sex chromosome and Bs element fixation is essential to understand the developing mechanisms involved in these especial chromosomes and speciation.

The present study presents evidence of the occurrence of MD involving these special chromosomes in fish karyotypes with high bi-brachial (biarmed) elements. Additionally we establish the chromosomal diversification rate per unit of time for various families of Perciformes. These data show that chromosomal diversification may be modeled by general biological characteristics within each family.

\section{MATERIALS AND METHODS}

We analyzed karyotypic data on 1332 species distributed into 66 families and 11 orders of bony fishes(Atheriniformes, Characiformes, Perciformes, Salmoniformes, Siluriformes, Tetraodontiformes, Mugiliformes, Gymnotiformes, Cyprinodontiformes, Cypriniformes, and Anguilliformes) (data to be presented in review form elsewhere). The total number of species analyzed included 52 species with sex chromosome systems and 39 species with 
Bs chromosomes. Diploid numbers and karyotype formulas were obtained from several databases, mainly reviews by Carvalho et al. (2008) and Arai (2011). The karyotype formulas were used to calculate the mean percentages of mono-brachial (acrocentric or telocentric) chromosomes for each species. Homogametic sex was considered the standard in species with simple or multiple sex chromosomes (e.g., ZZ, XX, $\mathrm{Z}_{1} \mathrm{Z}_{1} \mathrm{Z}_{2} \mathrm{Z}_{2}, \mathrm{X}_{1} \mathrm{X}_{1} \mathrm{X}_{2} \mathrm{X}_{2}$ ). In those species with more than one described karyotype, these were included only when having been showed for separate geographic areas and the possibility of polymorphism was excluded.

In order to obtain precise data on intrafamilial trends and due to the diversity of families included in the Order Perciformes, two families were studied in detail: Pomacentridae $\left(\mathrm{n}_{\mathrm{t}}=348 \mathrm{spp}\right.$, $\mathrm{n}_{\mathrm{a}}=38 / 11 \%$ analyzed here $)$ and Labridae $\left(\mathrm{n}_{\mathrm{t}}=453\right.$ spp; $n_{a}=49 / 11 \%$ analyzed here). We analyzed the relationship between the frequency of monobrachial chromosomes in karyotypes containing $\mathrm{B}$ and sex chromosomes using logistic regression model, with the Systat 12.0 software.

Considering that the proposed origin of Perciformes can be dated to 150 million years ago (mya) (Cantatore et al. 1994) and that their ancestral karyotype, as defined for Clupeocephala and Euteleostei, is $2 \mathrm{n}=48$ acrocentric chromosomes (Brum and Galetti 1997), we calculated the rate of karyotypic change per million years in ten of its families, selected in function of the number of species with available cytogenetic data. Families with more accurate fossil data were used as reference (Frickhinger 1995, Near et al. 2005, Patterson 1993, Murray 2001).

\section{RESULTS}

Data from the orders analyzed indicated a prevalence of karyotypes with few $(<33 \%)$ or many $(>66 \%)$ acrocentric chromosomes and a low number of karyotypes with balanced numbers of mono- and bi-brachial elements (Figure 1a). We emphasize

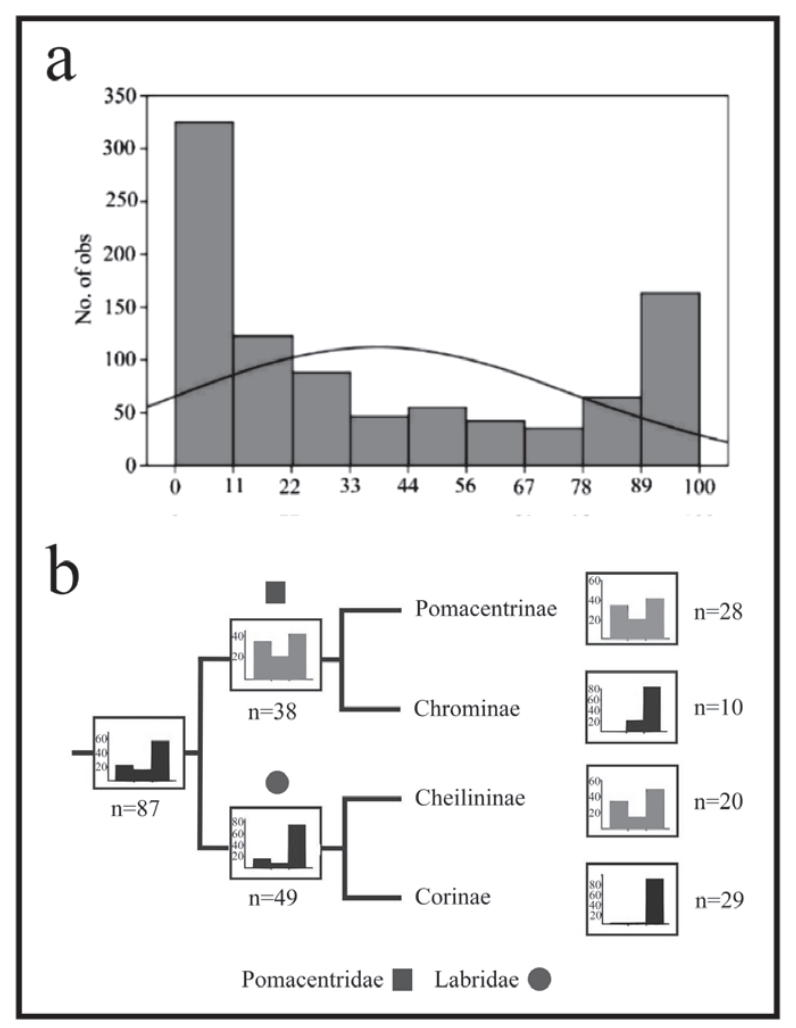

Figure 1 - Distribution of mono-brachial chromosome percentage in (a) karyotypes of 11 Actynopterigii Orders and (b) Pomacentridae and Labridae subfamilies. In (b), the first column corresponds to karyotypes with $<33 \%$ acrocentrics, while the last column corresponds to karyotypes with $>66 \%$ acrocentrics.

that these results correspond to the principal orders of Actinopterygii that exhibited the best conditions for conducting macroanalyses.

Intra-family analyses performed on two subfamilies of Pomacentridae indicated particular trends among them. In Pomacentrinae, a recognized polyphyletic group (Tang 2001, Cooper et al. 2009), karyotypes with "right" $>66 \%$ of acrocentric chromosomes; modal frequency of acrocentrics dislocated to the right of total distribution) or "left" $(<33 \%$ of acrocentric chromosomes; modal frequency of acrocentrics dislocated to the left of total distribution) trends were present (Figure 1b). In contrast, Chrominae showed a predominance of mono-brachial chromosomes. In Labridae, the subfamily Chelininae exhibited karyotypes with two tendencies ("right" and "left"), whereas Corinae shared the same "right" trend in karyotypes. 
Analysis of the occurrence of Bs and sex chromosomes in relation to the frequency of acrocentrics per karyotype showed nonrandom distribution. By contrast, a negative correlation was observed between the presence of these special chromosomes and groups with lower numbers of mono-brachial chromosomes (Figure 2).
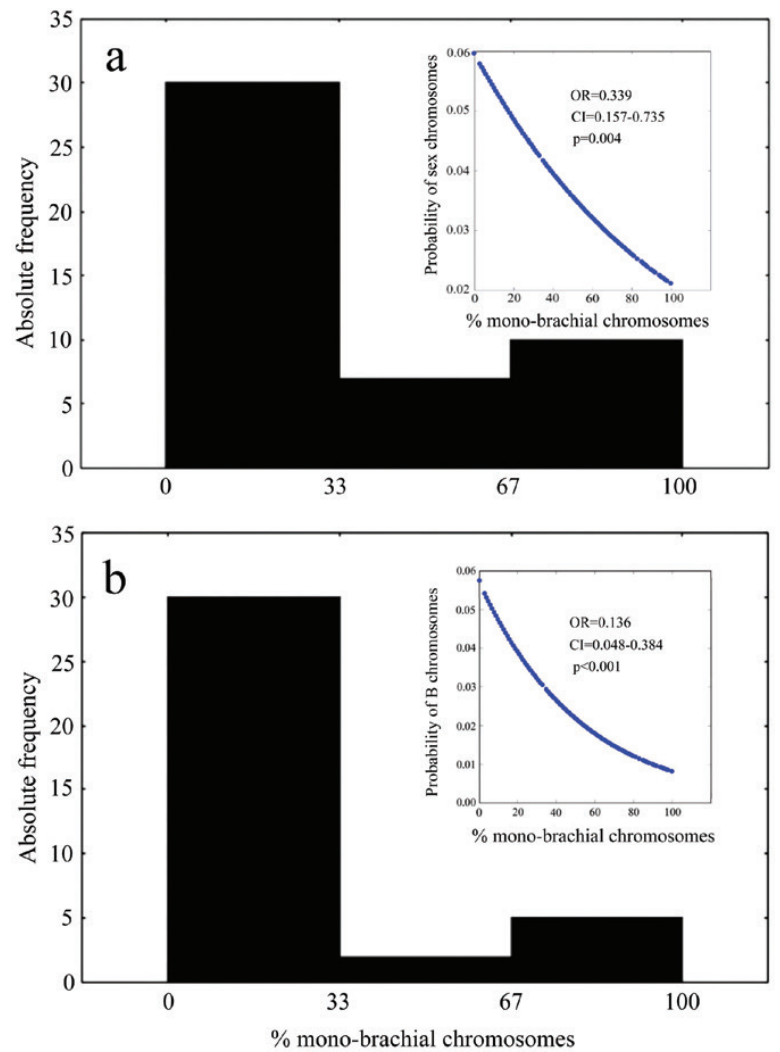

Figure 2 - Absolute frequencies of karyotypes of Actinopterygii species with (a) sex chromosome systems and (b) B chromosomes distributed into classes based on the percentage of mono-brachial chromosomes. The logistic regression predicting sex and Bs chromosomes and percentage of mono-brachial chromosomes was statistically significant $(p<0.001$ and $p=0.004)$. Both sex and Bs chromosomes are more likely to occur in karyotypes with a large number of bi-brachial chromosomes. $\mathrm{OR}=$ odds ratio; $\mathrm{CI}=95 \%$ confidence interval.

For some animal groups, cladistic analysis has been performed in order to determine the number of chromosomal rearrangements required to convert a karyotype proposed as primitive for a family into the karyotype of an extant species (Bickham and
Baker 1980). Here, we defined the divergence/time relationship starting from an ancestral karyotype of the Perciformes $(2 n=48$ acrocentrics) based on an estimated origin of this order. The data revealed different rates of rearrangement fixation among the families (Table I), allowing arbitrary subdivision into three groups: (I) low rate of divergence, (II) intermediate rate of divergence, and (III) groups that exhibit high chromosome differentiation relative to the basal karyotype of the order.

\section{DISCUSSION}

BS AND SEX Chromosomes ACCUMULATION IN

FISH GENOMES

The centromere drive model has been applied to explain karyotype evolution, where nonrandom distribution of chromosome types (mono-brachial vs bi-brachial) occurs, and also to the dynamics of B-chromosomes in animals and plants (Bidau and Martí 2004, Palestis et al. 2004a, b). In fish, probably under continuous selection of nonrandom segregation, most groups tend to achieve preferred karyotype formulas with mono- or bi-brachial chromosomes, while a small number of species exhibit equivalent mono- and bi-brachial elements. However, a correlation between sex systems and B chromosomes in karyotypes with a high or low number of acrocentric elements had not yet been established.

Macrotrends in the karyotypic distribution of mono- and bi-brachial elements exhibited by the groups showed significant correlations with the presence or absence of B and sex chromosomes. Cases of Bs chromosomes in fish have increasingly been identified in recent years, especially in the Neotropical region (Carvalho et al. 2008). Supernumerary chromosomes, albeit of independent origins, are notoriously recurrent in Characiformes ( $\mathrm{n}=31 \mathrm{spp}$.) and Siluriformes ( $\mathrm{n}=21 \mathrm{spp}$.) (Fenocchio and Bertollo 1990, Dias and Foresti 1993, Venere et al. 1999, Carvalho et al. 2008). In these orders, the frequency of $\mathrm{B}$ chromosomes is the highest found in all fish orders to date, including the large order Perciformes. 
TABLE I

Rates of chromosomal changes per million years in some families of Perciformes (I, low; II, intermediate; and III, fast).

\begin{tabular}{|c|c|c|c|c|c|c|}
\hline Family & m.y.a* & $\mathbf{N}$ & Changes & Mean & \multicolumn{2}{|c|}{ Changes $\left(10^{-2}\right) / \mathrm{m} . \mathrm{y}$} \\
\hline Haemulidae $^{1}$ & 57.80 & 14 & 2 & 0.142 & \multirow{3}{*}{ I } & 0.094 \\
\hline Centrarchidae $^{2}$ & 33.59 & 27 & 12 & 0.444 & & 0.296 \\
\hline Carangidae $^{1}$ & 52.00 & 26 & 52 & 2.000 & & 1.333 \\
\hline Sparidae $^{1}$ & 66.40 & 25 & 110 & 4.400 & \multirow{4}{*}{ II } & 2.933 \\
\hline Cichlidae $^{3}$ & 45.00 & 65 & 358 & 5.507 & & 3.671 \\
\hline Nototheniidae $^{4}$ & 23.00 & 21 & 120 & 5.714 & & 3.809 \\
\hline Labridae $^{1}$ & 57.80 & 42 & 254 & 6.047 & & 4.031 \\
\hline Pomacentridae $^{1}$ & 52.00 & 43 & 395 & 9.186 & \multirow{3}{*}{ III } & 6.124 \\
\hline Percidae $^{1}$ & 57.80 & 22 & 239 & 10.863 & & 7.242 \\
\hline Gobiidae $^{1}$ & 52.00 & 41 & 550 & 13.414 & & 8.943 \\
\hline
\end{tabular}

*Age of first fossil record for the family, except for Nototheniidae and Centrarchidae, which were estimated by molecular clock. N, species number. Changes, rearrangements detected in relation to the ancestral Perciformes karyotype. ${ }^{1}$ Frickhinger $1995 ;{ }^{2}$ Near et al. 2005; ${ }^{3}$ Murray 2001; ${ }^{4}$ Near 2009. Estimative of changes/time based on the probable origin of Perciformes, 150 m.y.a (according to Cantatore et al. 1994).

More revealing is the fact that both orders show a tendency toward retaining bi-brachial chromosomes, which is also the most frequent morphology in their supernumerary chromosomes (Carvalho et al. 2008). Morphologically and numerically, the $\mathrm{B}$ chromosomes of fish may range from dot-like elements to large metacentrics close to the size of the larger pairs of the A karyotype (e.g., MoreiraFilho et al. 2004). Up to 16 B chromosomes can occur in a single individual (Erdtmann et al. 1990).

Predominance of B chromosomes in females has been observed in Astyanax scabripinnis, where in some populations, one or two large metacentric B chromosomes, shown to be isochromosomes, were present (Mestriner et al. 2000). In other wellanalyzed populations of this species, significant differences were observed between sexes; B chromosomes occurred in females but were absent in males (Vicente et al. 1996, Mizoguchi and MartinsSantos 1997). A large B chromosome has also been reported in several other Astyanax populations and species (e.g., Salvador and Moreira-Filho 1992, Porto-Foresti et al. 1997, Néo et al. 2000, MoreiraFilho et al. 2001), which suggests that meiotic drive favors metacentricity in Characiformes, and by extrapolation, in Siluriformes, through the accumulation of bi-brachial elements.

Analyses of the synaptonemal complex in Moenkhausia sanctaefilomenae (Characidae) suggest that the maintenance of B chromosomes may be related to their behavior in prophase I (formation of normal bivalents), which could favor their transmission (Portela-Castro et al. 2001). Despite the evidence that these B chromosomes show some accumulation mechanism, analysis of B chromosome segregation in Prochilodus lineatus (Characiformes), obtained from crosses involving individuals with different numbers of Bs, did not reveal asymmetric segregation (Oliveira et al. 1997). This could support the idea that in orders with a tendency to capture bi-brachial chromosomes, dotlike elements may not be affected by meiotic drive.

$\mathrm{B}$ chromosomes are also found in orders with a tendency toward the accumulation of acrocentric elements ("right trend"), such as Perciformes, but much less frequently. However, both their absolute and relative occurrence is extremely low and, when present, they are usually microchromosomes 
(Carvalho et al. 2008). In this case, the mechanism of their accumulation could be associated with the preference exhibited by the functional pole of the female germ cells for capturing more centromeres, a condition compatible with centromeric drive for acrocentric accumulation (Pardo-Manuel de Villena and Sapienza 2001a, Palestris et al. 2004a, b).

Sex determination in fish is extremely diversified and labile (Mank et al. 2006). In this group, heteromorphic sex chromosome systems have been observed in about $10 \%$ of cytogenetically studied species (Devlin and Nagahama 2002), where XY or ZW types could arise repeatedly and independently. In some clades, examples of male or female heterogamety may coexist (Andreata et al. 1992, 1993), along with hermaphroditism (Mank et al. 2006), indicating their interchangeable evolutionary nature, as proposed by Olmo et al. (1987) for lizards. On the other hand, the occurrence of a same sex chromosome system (e.g., XY or ZW) in several species of phylogenetically related families, indicates the chromosomal emergence of a latent and shared model of sex determination, as suggested to explain the independent appearance of ZW chromosomes in Parodontidae, Anostomidae, Hemiodontidae and Prochilodontidae (Molina et al. 1998).

The emergence and further evolution of sex chromosomes may be triggered by suppression of crossing over in a heteromorphic chromosome region, independent of the involved rearrangement (Herrero et al. 1992, Charlesworth 2002). The suppression of intra-chromosomal recombination between homologs carrying sex-determining genes allows further degeneration of the $\mathrm{Y}$ or $\mathrm{W}$ chromosome by accumulation of deleterious mutations and repetitive non-coding sequences (Singh etal. 1980, Charlesworth and Charlesworth 2000). The same considerations apply to multiple sex chromosome systems in fish that derive mainly from centric fusions and, to a lesser extent, tandem fusions (Morescalchi et al. 1990, Bertollo et al. 1997, 2000, Bertollo and Mestriner 1998, Caputo et al. 2001, Cioffi and Bertollo 2010).
In these cases, the neo-Y or neo-W chromosomes undergo a new degeneration cycle (Charlesworth and Charlesworth 2000, Charlesworth 2002).

Absence of recombination makes sex chromosomes more sensitive to meiotic drive (Hurst and Pomiankowski 1991), allowing the accumulation of drivers, including centromere sequences. Interestingly, if the meiotic drive trend of the precursors of sex chromosomes were maintained after sex chromosome differentiation, this phenomenon could cause sex-ratio distortion of the progeny in the absence of suppressors (Rutkowska and Badyaev 2008). In fact, sex chromosome systems do not show random distribution among the analyzed Teleostei groups. Although heteromorphic sex chromosomes also occur in groups with high numbers of monobrachial chromosomes, such as Perciformes (e.g., Ueno and Takai 2008), their presence is strongly correlated with those groups with a propensity for the fixation of bi-brachial elements, such as in Characiformes and Siluriformes, suggesting that meiotic drive could have aided the establishment of newly arisen sex chromosome systems. Given that the drive mechanism helps establish a new sex system, it is likely counterbalanced by drive suppressors; otherwise the species could become extinct (Jaenike 2001).

The reversion of preferential spindle polarity apparently occurred repeatedly during the evolution of lineages in the same fish group, which could explain strongly differentiated karyotypes in related species (Pardo-Manuel de Villena and Sapienza 2001b). A recurrentquestion is whetherbiological, environmental, and stochastic factors could also interfere in karyotypic preservation or change in a taxon. The answer is undoubtedly yes. Once a chromosomal mutation appears, the rearranged chromosome, either with centric fusion or pericentric inversion, would have differential conditions for fixation or loss, depending on the success in being preferentially captured by the oocyte spindle pole at female meiosis. Without any 
selective pressure, this situation might lead to the establishment of a karyotypic pattern for a group or related species. However, under selective or chance effects, as defined in many karyotype diversification models, different karyotypic patterns other than those expected only for drive, should occur. In fact, several factors, such as greater fitness, establishment of post-zygotic barriers, increased viability, stochastic events, or factors intrinsic to the species, even if they act against the particular segregation norm, can act in this process. Thus, karyotype constancy within a group, signaled by a defined meiotic drive trend, will depend on the strength of the drive, the evolution of suppressors, the resulting conflict, and the selective and chance factors that may weaken or boost the trend.

\section{ASYNCHRONIC CHROMOSOME EVOLUTION IN}

PERCIFORMES FAMILIES

Numerical and structural rearrangements in fish are frequently fixed in small demes (Moreira-Filho and Bertollo 1991), whereas other factors conducive to karyotype diversification in other vertebrates, such as high reproductive rate, restricted mobility or vagility, and strongly limited ecological niches (Arnason 1972), may also have contributed to karyotypic diversity in this group. However, general macro-trends within large taxonomic groups are not expected from these factors.

The Perciformes families can be separated into three distinct groups based on the rates of change in the karyotypic macro-structures (Table I). Group I comprises families with a high degree of chromosomal conservatism, such as Haemulidae, Centrarchidae and Carangidae (0.094-1.333 x 10-2 changes/m.y.). Group II includes families with intermediate rates of chromosomal changes (2.933$4.031 \times 10^{-2}$ changes/m.y.), represented in ascending order by Sparidae, Cichlidae, Nototheniidae, and Labridae. Group III includes families with the highest rates of karyotypic diversification (6.1248.943 changes x $10^{-2} / \mathrm{m} . y$.), such as Pomacentridae, Percidae and Gobiidae, in order of divergence.
Some biological and biogeographic factors appear to be related to a lower or higher rate of chromosomal change. In group I, the Haemulidae family, with the lower rate of evolutionary change, is one of the most numerically, ecologically, and economically important reef fish groups in the New World (Ferreira et al. 2004). This family is distributed in wide marine regions, with many estuarine and rare freshwater species forming large populations (Nelson 2006). In addition to vicariant events, the ecological mechanisms of speciation that contributed to species richness in this family (Rocha and Molina 2008), combined with special stable features of its karyotype (Nirchio et al. 2007) could be the major causes of karyotype stasis. However, conservative karyotypes seem to be involved in the reduction of post-zygotic reproductive isolation (Molina et al. 2013) by the occurrence of natural and induced hybrids in the Centrarchidae and Carangidae families (Koppelman 1994, Murakami et al. 2007).

In group II, the families Sparidae, Cichlidae, Labridae, and Nototheniidae represent groups with a number of specialized features. Specializations can be identified with regards to their trophic levels (Rüber et al. 1999, Day 2002, Kocher 2004), physiological adaptations (Kock 1992, Eastman 1993), behavior, reproductive patterns, and sex determination systems (Sale 1991). Two of these families are biological models in freshwater and marine environments. Cichlids are freshwater fishes that are mainly distributed in landmasses of Gondwanan origin (Africa, Central and South America, Madagascar, and India/Sri Lanka) (Nelson 2006), showing explosive radiations in the Great Lakes of East Africa (Genner et al. 2007). Their species richness, morphological and color diversity, and complex behaviors supporting a sophisticated social system, have made them model organisms for the study of speciation and adaptive evolution (Kocher 2004). Labridae, the second largest family of marine fishes and the third largest 
group of Perciformes, comprises specialized forms displaying complex social systems and changes of sex, and subject to important geographic and ecological partitions (Sale 1991).

In Group III, owing to their biological patterns, several species are also important models for ecological (Ceccarelli et al. 2001), evolutionary (Cooper et al. 2009) and ethological studies (Malavasi et al. 2008). All the Pomacentridae, Percidae and Gobiidae families are subject to strong ecological and geographic fragmentations (Drew and Barber 2009, Hollingsworth and Near 2008, Rüber et al. 2003). All these characteristics are in agreement with their high rates of fixation of chromosomal rearrangements.

Extensive analyses in certain marine fishes suggest that karyotypes of phylogeneticallyrelated groups demonstrate a tendency toward the same type of chromosomal rearrangements (Molina 2007) during their evolutionary history (orthoselective process). Indeed, processes of differential fixation of arrangements, such as those observed in subfamilies of Pomacentridae and Labridae, support the occurrence of orthoselective processes at microscale, modeling the karyotype of fish groups. Although the causes of rearrangements can be varied, the occurrence of MD could represent the mechanism by which the fixation of certain rearrangements would occur preferentially.

The precise association between karyotypes with a high number of bi-brachial chromosomes and sex chromosomes and Bs chromosomes surprisingly reveal a pattern of meiotic drive preferentially associated to specific chromosome types rather than the number of centromeres in fish. Although further investigations are needed to clarify the factors involved in the meiotic drive mechanism, repetitive sequences may play a role in this process. Indeed, repetitive DNA sequences have been identified as a promoter of high dynamism in the karyotypes of some groups of Perciformes (Molina 2007, Schneider et al. 2013).
These data have implications for karyotypic evolution in macro- and micro-scales in Actinopterygii fish, also to providing a plausible explanation for the preferential phylogenetic accumulation in some clades of sex and B chromosomes associated to biarmed karyotypes. Further efforts should be focused on a better understanding of the functional aspects of MD in fish.

\section{ACKNOWLEDGMENTS}

The authors are grateful to Conselho Nacional de Desenvolvimento Científico e Tecnológico (CNPq) for the financial support (Proc. No. 556793/20099), National Institute of Science and Technology in Marine Sciences (INCT/CNPq) and to Dr. Juan Pedro M. Camacho for critical comments on early draft of the manuscript.

\section{RESUMO}

Mecanismos de acúmulo baseados em deriva centromérica típica ou de cromossomos portadores de inversões pericêntricas mostram-se adequados à diferenciação cariotípica mais ampla nas principais ordens de Actinopterygii. Aqui nós mostramos que a deriva meiótica nos peixes é também apoiada pela fixação preferencial de sistemas de cromossomos sexuais e cromossomos B em ordens com cariótipos predominantemente formados por elementos bi-braquiais. O mosaico de tendências cromossômicas que atuam em nível infra-familiar em peixes poderia ser explicado pela interação do processo direcional de deriva meiótica agindo como pano de fundo, modulada em menor escala por fatores adaptativos ou propriedades cariotípicas específicas de cada grupo, conforme proposto pelo modelo de ortoseleção.

Palavras-chave: Actinopterygii, cromossomos Bs, deriva centromérica, evolução cromossômica, cromossomos sexuais.

\section{REFERENCES}

AlmeIDA-Toledo LF, DANIEL-SILVA MFZ, MoyséS CB AND FORESTI F. 2007. Chromosome variability in Gymnotiformes. In: Pisano E, Ozouf-Costaz C, Foresti F and Kapoor BG (Eds), Fish cytogenetics. Enfield, Science Publishers, p. 17-40. 
ANDrEatA AA, ALMEIDA-TOLEDO LF, OLIVEIRACAND TOLEDO FILHO AS. 1992. Chromosome studies in Hypoptopomatinae (Pisces, Siluriformes, Loricariidae). I. XX/XY sex chromosome heteromorphism in Pseudotocinclus tietensis. Cytologia 57: 369-372.

ANDREATA AA, ALMEIDA-TOLEDO LF, OLIVEIRA C AND TOLEDO FILHO AS. 1993. Chromosome studies in Hypoptopomatinae (Pisces, Siluriformes, Loricariidae). II. ZZ/ZW sexchromosome system, B chromosomes, and constitutive heterochromatin differentiation in Microlepidogaster leucofrenatus. Cytogenet Cell Genet 63: 215-220.

ARAI R. 2011. Fish karyotypes: A check list. Tokyo: Springer.

ARNASON U. 1972. The role of chromosomal rearrangement in mammalian speciation with special reference to Cetacea and Pinnipedia. Hereditas 70: 113-118.

BERRA TM. 2001. Freshwater fish distribution, San Diego: Academic Press.

Bertollo LaC, Born GG, Dergam JA, Fenocchio AS AND MOREIRA-FILHO O. 2000. A biodiversity approach in the Neotropical Erythrinidae fish, Hoplias malabaricus. Karyotypic survey, geographic distribution of cytotypes and cytotaxonomic considerations. Chrom Res 8: 603-613.

Bertollo LAC, Fontes MS, Fenocchio AS AND CANO J. 1997. The X1X2Y sex chromosome system in the fish Hoplias malabaricus. I. G-, C- and chromosome replication banding. Chrom Res 5: 493-499.

Bertollo LAC And Mestriner CA. 1998. The X1X2Y sex chromosome system in the fish Hoplias malabaricus (Pisces, Erythrinidae). II. Meiotic analyses. Chrom Res 6: 141-147.

BICKHAM JW AND BAKER RJ. 1979. Canalization model of chromosomal evolution. Bull Carnegie Mus Nat Hist 13: 70-84.

BICKHAM JW AND BAKER RJ. 1980. Karyotypic evolution in bats: evidence of extensive and conservative chromosomal evolution in closely related taxa. Syst Zool 29: 239-253.

BIDAU CJ AND MARTí DA. 2004. B chromosomes and Robertsonian fusions of Dichroplus pratensis (Acrididae): intraspecific support for the centromeric drive theory. Cytogenet Genome Res 106: 347-350.

Bone Q AND MoORE RH. 2008. Biology of fishes, New York: Taylor and Francis Group.

BRUM MJI. 1995. Correlações entre a filogenia e a citogenética de peixes teleósteos. Rev Brasil Genét 2: 5-42.

BRUM MJI AND GALETTI JR PM. 1997. Teleostei ground plan karyotype. J Comp Biol 2: 91-102.

Camacho JPM, Sharbel TF And Beukeboom LW. 2000. B chromosome evolution. Phil Trans R Soc Lond B Biol Sci 355: $163-178$.

Cantatore P, Roberti M, Pesole G, Ludovico A, Milella F, Gadaleta MN AND SACCONE C. 1994. Evolutionary analysis of cytochrome b sequences in some Perciformes: Evidence for a slower rate of evolution than in mammals. J Mol Evol 39: 589-597.

Caputo V, Machella N, Nisi-Cerioni P AND Olmo E. 2001. Cytogenetics of nine species of Mediterranean blennies and additional evidence for an unusual multiple sex-chromosome system in Parablennius tentacularis (Perciformes, Blenniidae). Chrom Res 9: 3-12.
CARvalho RA, Martins-Santos IC And Dias AL. 2008. B chromosomes: an update about their occurrence in freshwater Neotropical fishes (Teleostei). J Fish Biol 72: 1907-1932.

CECCARELli DM, Jones GP AND MCCOOK LS. 2001. Territorial damselfish as determinants of the structure of benthic communities on coral reefs. Oceanogr Mar Biol Annu Rev 39: 355-389.

Charlesworth B. 2002. The evolution of chromosomal sex determination. In: Chadwick D and Goode J (Eds), The genetics and biology of sex determination. Chichester: J Wiley \& Sons, p. 207-224.

Charlesworth B And Charlesworth D. 2000. The degeneration of Y chromosomes. Phil Trans R Soc Lond B Biol Sci 355: 1563-2572.

Cioffi MB AND BerTollo LAC. 2010. Initial steps of an XY sex chromosome differentiation in Hoplias malabaricus and correlations with the origin of the X1X2Y sex chromosome system in this fish group. Heredity 105: 554-561.

Comber SCL AND Smith C. 2004. Polyploidy in fishes: Patterns and processes. Biol J Linn Soc 82: 431-442.

CoOper WJ, Smith LL AND Westneat MW. 2009. Exploring the radiation of a diverse reef fish family: phylogenetics of the damselfishes (Pomacentridae), with new classifications based on molecular analyses of all genera. Mol Phylog Evol 52: 1-16.

DAY JJ. 2002. Phylogenetic relationships of the Sparidae (Teleostei: Percoidei) and implications for convergent trophic evolution. Biol J Linn Soc 76: 269-301.

DEVLIN RH AND NAGAHAMA Y. 2002. Sex determination and sex differentiation in fish: an overview of genetic, physiological, and environmental influences. Aquaculture 208: 191-364.

DiAs AL AND Foresti F. 1993. Cytogenetic studies on fishes of the family Pimelodidae (Siluroidei). Rev Brasil Genét 16: 585-600.

DREW J AND BARBER PH. 2009. Sequential cladogenesis of the reef fish Pomacentrus moluccensis (Pomacentridae) supports the peripheral origin of marine biodiversity in the Indo-Australian archipelago. Mol Phylogenet Evol 53: 335-339.

Eastman JT. 1993. Antarctic Fish Biology. San Diego: Academic Press.

ERdtMANn B, CALCAGNOTO D, RABOLINI L AND MALABARBA LR. 1990. Variabilidade cromossômica em Callichthys callichthys (Callichthyidae, Pisces). Ciênc Cult 42: 452.

FenOCCHIO AS AND BerTollo LAC. 1990. Supernumerary chromosomes in a Rhamdia hilarii population (Pisces, Pimelodidae). Genetica 81: 193-198.

Ferreira CEL, Floeter SR, Gasparini JL, Joyeux JC AND FERREIRA BP. 2004. Trophic structure patterns of Brazilian reef fishes: a latitudinal comparison. J Biogeogr 31: 1093-1106.

FRICKHINGER KA. 1995. Fossil Atlas Fish, Blacksburg: Tetra Press. GALETTI JR PM, AgUILAR CTAND MOLINA WF. 2000. An overview on marine fish cytogenetics. Hydrobiologia 420: 55-62. 
Genner MJ, Seehausen O, Lunt DH, Joyce DA, Shaw PW, CARVALHO GR AND TURNER GF. 2007. Age of cichlids: new dates for ancient lake fish radiations. Mol Biol Evol 24: $1269-1282$.

Helfman GS, Collette BB, Facey DE AND Bowen BW. 2009. The diversity of fishes: biology, evolution, and ecology. Oxford: Wiley-Blackwell.

Herrero P, De la Torre J, Gosálvez J AND Sumner AT. 1992. Heterochromatin characterization of sex chromosomes in Triturus marmoratus (Urodela, Salamandridae). Cytogenet Cell Genet 60: 150-153.

Hoekstra HE AND HoEKstra JM. 2001. An unusual sexdetermination system in South American field mice (Genus Akodon): The role of mutation, selection, and meiotic drive in maintaining XY females. Evolution 55: 190-197.

HOLLINGSWORTH JR PR AND NEAR TJ. 2008. Temporal patterns of diversification and microendemism in eastern highland endemic barcheek darters (Percidae: Etheostomatinae). Evolution 63: 228-243.

HURST LD AND POMIANKOWSKI A. 2001. Causes of sex ratio bias may account for unisexual sterility in hybrids: a new explanation of Haldane's rule and related phenomena. Genetics 128: 841-858.

JAENIKE J. 2001. Sex chromosome meiotic drive. Ann Rev Ecol Syst 32: 25-49.

KING M. 1981. Chromosome change and speciation in lizards. In: White MJD, Atchley WR and Woodruff D (Eds), Evolution and Speciation. London: Cambridge University Press, p. 262-285.

KING M. 1993. Species Evolution: The role of chromosome change. Cambridge: Cambridge University Press.

KOCHER TD. 2004. Adaptive evolution and explosive speciation: the cichlid fish model. Nat Rev Genet 5: 288-298.

KocK KH. 1992. Antarctic fish and fisheries, Cambridge: Cambridge University Press.

KOPPELMAN JB. 1994. Hybridization between smallmouth bass, Micropterus dolomieui and spotted bass, $M$. punctulatus, in the Missouri River System, Missouri. Copeia 1994: 204-211.

LEMAIRE-ADKInS R AND HunT PA. 2000. Nonrandom segregation of the mouse univalent $\mathrm{X}$ chromosome: evidence of spindle-mediated meiotic drive. Genetics 156: 775-783.

LYTTLE TW. 1993. Cheaters sometimes prosper: distortion of segregation by meiotic drive. Trends Genet 9: 205-210.

Malavasi S, Collatuzzo S AND TORRICElli P. 2008. Interspecific variation of acoustic signals in Mediterranean gobies (Perciformes, Gobiidae): comparative analysis and evolutionary outlook. Biol J Linn Soc 93: 763-778.

MANK JE, PROMISLOW DEL AND AVISE JC. 2006. Evolution of alternative sex-determining mechanisms in teleost fishes. Biol J Linn Soc 87: 83-93.

Mestriner CA, GALETti JR PM, VALENTINI S, RUIZ IGR, ABEL LDS, MOREIRA-FILHO O AND CAMACHO JPM. 2000. Structural and functional evidence that a B chromosome in the characid fish Astyanax scabripinnis is an isochromosome. Heredity 85: 1-9.
Mizoguchi SMHN AND Martins-SAntos IC. 1997. Macroand microchromosomes B in females of Astyanax scabripinnis. Hereditas 127: 249-253.

Molina WF. 2007. Chromosomal changes and stasis in marine fish groups. In: Pisano E, Ozouf-Costaz C, Foresti F and Kapoor BG (Eds), Fish cytogenetics. Enfield, Science Publishers, p. 69-110.

Molina WF, Costa GWF, Cioffi MB AND Bertollo LAC. 2012. Chromosomal differentiation and speciation in sister-species of Grammatidae (Perciformes) from the Western Atlantic. Helgol Mar Res 66: 363-370.

Molina WF, Costa GWWF, Soares RX, AFFonso PRAM, Cioffi MB, AraúJo WC and Bertollo LAC. 2013. Extensive chromosome conservatism in Atlantic butterflyfishes, genus Chaetodon Linnaeus, 1758: Implications for the high hybridization success. Zoolog Anz 253: 137-142.

Molina WF AND GALETTI JR PM. 2004. Multiple pericentric inversions and chromosome divergence in the reef fishes Stegastes (Perciformes, Pomacentridae). Genet Mol Biol 27: 543-548.

Molina WF, Margarido VP AND Galetti JR PM. 2007. Natural triploidy in Leporinus cf. elongatus bearing sex chromosomes. Genet Mol Biol 30: 567-569.

Molina WF, SCHMID M AND GALETTI JR PM. 1998. Heterochromatin and sex chromosomes in the Neotropical fish genus Leporinus (Characiformes, Anostomidae). Cytobios 94: 141-149.

MoreirA-FILHO O AND Bertollo LAC. 1991. Astyanax scabripinnis (Pisces, Characidae): a species complex. Rev Brasil Genét 14: 331-357.

Moreira-Filho O, FenOcChio AS, PAStori C AND Bertollo LAC. 2001. Occurrence of a metacentric macrochromosome $\mathrm{B}$ in different species of the genus Astyanax (Pisces, Characidae, Tetragonopterinae). Cytologia 66: 59-64.

Moreira-Filho O, Galetti JR PM AND Bertollo LAC. 2004. B chromosomes in the fish Astyanax scabripinnis (Characidae, Tetragonopterinae): an overview in natural populations. Cytogenet Genome Res 106: 230-234.

Morescalchi A, Hureau JC, Olmo E, Ozouf-Costaz C, Pisano E and Stanyon R. 1990. A multiple sexchromosome system in Antarctic ice-fishes. Polar Biol 11: 655-661.

Motta-Neto CC, Cioffi MB, Bertollo LAC And Molina WF. 2011b. Extensive chromosomal homologies and evidence of karyotypic stasis in Atlantic grunts of the genus Haemulon (Perciformes). J Exp Mar Biol Ecol 401: 75-79.

Motta-Neto CC, Cioffi MB, Bertollo LAC and Molina WF. 2011a. Molecular cytogenetic analysis of Haemulidae fish (Perciformes): Evidence of evolutionary conservation. J Exp Mar Biol Ecol 407: 97-100.

MotTa-Neto PA, Lima-Filho PA, AraúJo WC, Bertollo LAC AND MolinA WF. 2012. Differentiated evolutionary pathways in Haemulidae (Perciformes): karyotype stasis versus morphological differentiation. Rev Fish Biol Fisher 22: 457-465. 
MuraKami K, SHelley JA, RANDALl JE AND SuZumoto AY. 2007. Two hybrids of carangid fishes of the genus Caranx, C. ignobilis x $C$. melampygus and $C$. melampygus x $C$. sexfasciatus, from the Hawaiian Islands. Zool studies 46: 186-193.

MURRAY AM. 2001. The fossil record and biogeography of the Cichlidae (Actinopterygii: Labroidei). Biol J Linn Soc 74: 517-532.

NEAR TJ. 2004. Estimating divergence times of notothenioid fishes using a fossil-calibrated molecular clock. Antarctic Sci 16: 37-44.

NeAR TJ, Bolnick DI AND Wainwright PC. 2005. Fossil calibrations and molecular divergence time estimates in centrarchid fishes (Teleostei: Centrarchidae). Evolution 59: 1768-1782.

NELSON JS. 2006. Fishes of the World. $4^{\text {th }}$ ed., New York: J Wiley \& Sons.

NÉo DM, Bertollo LAC AND MoreirA-Filho O. 2000. Morphological differentiation and possible origin of $\mathrm{B}$ chromosomes in natural Brazilian populations of Astyanax scabripinnis (Pisces, Characidae). Genetica 108: 211-215.

Nirchio M, Gaviria JI, Oliveira C, Ferreira IA AND MARTINS C. 2007. Cytogenetic analysis of three species of the genus Haemulon (Teleostei: Haemulinae) from Margarita Island, Venezuela. Genetica 131: 135-140.

Oliveira C, Almeida-Toledo L AND Foresti F. 2007. Karyotypic evolution in Neotropical fishes. In: Pisano E, Ozouf-Costaz C, Foresti F and Kapoor BG (Eds), Fish cytogenetics. Enfield, Science Publishers, p. 111-164.

Oliveira C, SABOya SMR, Foresti F, SEnhorini JA AND BERNARDINO G. 1997. Increased B chromosome frequency and absence of drive in the fish Prochilodus lineatus. Heredity 79: 473-476.

OLMO E, ODIERNA G AND CAPRIGLIONE T. 1987. Evolution of sex-chromosomes in lacertid lizards. Chromosoma 96: 33-38.

PALESTIS BG, BURT A, JONES RN AND TRIVERS R. 2004a. $\mathrm{B}$ chromosomes are more frequent in mammals with acrocentric karyotypes: support for the theory of centromeric drive. Proc R Soc Lond B 271: 22-24.

Palestis BG, Trivers R, Burt A AND JONES RN. 2004b. The distribution of $\mathrm{B}$ chromosomes across species. Cytogenet Genome Res 106: 151-158.

Pardo-Manuel De Villena F and Sapienza C. 2001a. Nonrandom segregation during meiosis: the unfairness of females. Mamm Genome 12: 331-339.

Pardo-Manuel De Villena F AND SAPIENZA C. $2001 \mathrm{~b}$. Female meiosis drives karyotypic evolution in mammals. Genetics 159: 1179-1189.

PATTERSON C. 1993. An overview of the early fossil record of acanthomorphs. Bull Mar Sci 52: 29-59.

Portela-CAStro ALB, JÚlio Jr HF AND Nishiyama PB. 2001. New occurrence of microchromosomes B in Moenkhausia sanctaefilomenae (Pisces, Characidae) from the Paraná River of Brazil: analysis of the synaptonemal complex. Genetica 110: 277-283.
Porto-Foresti F, Oliveira C, MAISTRO EL AND Foresti F. 1997. Estimated frequency of B chromosomes and population density of Astyanax scabripinnis paranae in a small stream. Braz J Genet 20: 377-380.

Rocha EC AND Molina WF. 2008. Cytogenetic analysis in western Atlantic snappers (Perciformes, Lutjanidae). Genet Mol Biol 31: 461-467.

Ross JA, URTON JR, BOLAND J, SHAPIRO JD AND PEICHEL CL. 2009. Turnover of sex chromosomes in the stickleback fishes (Gasterosteidae). PLoS Genet 5: 1-12.

RÜBER L, VAN TASSELL JL AND ZARDOYA R. 2003. Rapid speciation and ecological divergence in the American seven-spined gobies (Gobiidae, Gobiosomatini) inferred from a molecular phylogeny. Evolution 57: 1584-1598.

RÜBER L, VERHEYEN E AND MEYER A. 1999. Replicated evolution of trophic specializations in an endemic cichlid fish lineage from Lake Tanganyika. Proc Natl Acad Sci USA 96: 10230-10235.

RUTKOWSKA J AND BADYAEV AV. 2008. Meiotic drive and sex determination: molecular and cytological mechanisms of sex ratio adjustment in birds. Phil Trans R Soc Lond B 363: 1675-1686.

SALE PF. 1991. The Ecology of Fishes on Coral Reefs. Academic Press, San Diego.

SALVAdOR LB AND MOREIRA-FilHo O. 1992. B chromosomes in Astyanax scabripinnis (Pisces, Characidae). Heredity 69: $50-56$.

Schneider CH, Gross MC, Terencio ML, CARmo EJ, MARTINS C AND FELDBERG E. 2013. Evolutionary dynamics of retrotransposable elements Rex1, Rex3 and Rex6 in neotropical cichlid genomes. BMC Evol Biol 13: 152.

Singh L, PURDOM IF AND Jones KW. 1980. Sex chromosome associated satellite DNA: evolution and conservation. Chromosoma 79: 137-157.

TAlbert PB, BAyes JJ AND Henikoff S. 2009. Evolution of centromeres and kinetochores: a two-part fugue. In: De Wulf P and Earnshaw WC (Eds), The kinetochore. New York: Springer, p. 193-230.

TANG KL. 2001. Phylogenetic relationships among damselfishes (Teleostei: Pomacentridae) as determined by mitochondrial DNA data. Copeia 3: 591-601.

UENO K AND TAKAI A. 2008. Multiple sex chromosome system of $\mathrm{X} 1 \mathrm{X} 1 \mathrm{X} 2 \mathrm{X} 2 / \mathrm{X} 1 \mathrm{X} 2 \mathrm{Y}$ ) type in lutjanid fish, Lutjanus quinquelineatus (Perciformes). Genetica 132: 35-41.

ULLER T AND BADYAEV AV. 2009. Evolution of "determinants" in sex-determination: A novel hypothesis for the origin of environmental contingencies in avian sex-bias. Sem Cell Dev Biol 20: 304-312.

Venere PC, Miyazawa CS AND Galetti JR PM. 1999. New cases of supernumerary chromosomes in Characiform fishes. Genet Mol Bio. 22: 345-349.

VicARI MR, PAZZA R, ARTONI RF, MARGARIDO VP AND Bertollo LAC. 2006. Cytogenetics and Biogeography: Considerations about the natural origin of Hoplias malabaricus (Characiformes, Erythrinidae) on the Iguaçu River. Braz Arch Biol Technol 49: 297-303. 
Vicente VE, MOREIRA-FILHO O AND CAMACHO JPM. 1996. Sex-ratio distortion associated to the presence of a B chromosome in Astyanax scabripinnis (Pisces, Characidae). Cytogenet Cell Genet 74: 70-75.

WhITE MJD. 1973. Animal cytology and evolution, $3^{\text {rd }}$ ed., Cambridge: Cambridge University Press.

WhITE MJD. 1978. Modes of speciation, San Francisco: W.R. Freeman and Company.

WyttenBach A, Borodin P AND HaUSSER J. 1998. Meiotic drive favors Robertsonian metacentric chromosomes in the common shrew (Sorex araneus, Insectivora, mammalia). Cytogenet Cell Genet 83: 199-206.
YoshidA K AND KitANO J. 2012. The contribution of female meiotic drive to the evolution of neo-sex chromosomes. Evolution 66: 3198-3208.

ZIMMERING S, SANDLER L AND NICOLETTI B. 1970. Mechanisms of meiotic drive. Ann Rev Genet 4: 409-436. 